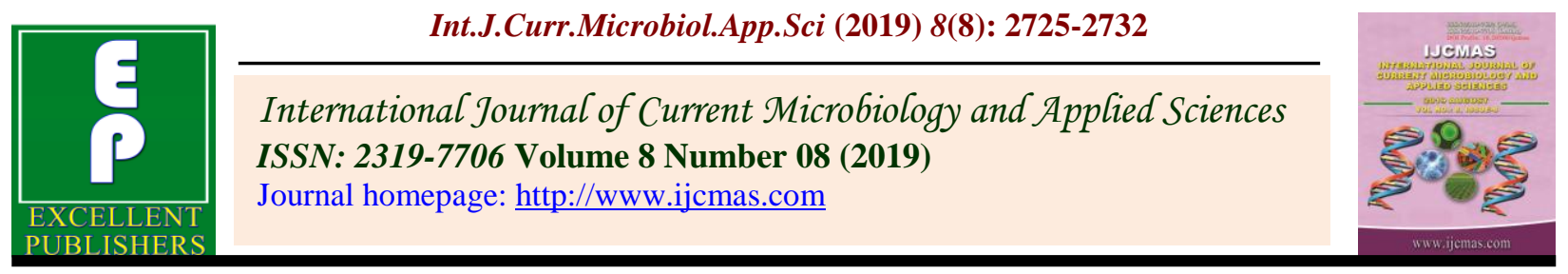

Original Research Article

https://doi.org/10.20546/ijcmas.2019.808.314

\title{
Influence of Selective Combination of City Compost and NPK Fertilization on Growth and Yield of Spinach (Spinacia oleracea L.)
}

\author{
Nilesh Nirgude ${ }^{1}$, D. K. Mishra ${ }^{2 *}$, Raj Kumar Dhakad ${ }^{1}$ and Deepak Singune ${ }^{1}$ \\ ${ }^{1}$ Dr. B.R. Ambedkar University of Social Science, Mhow - 453441, (M.P), India \\ ${ }^{2}$ Krishi Vigyan Kendra, Kasturbagram, Indore, (M.P.) 452020, India \\ *Corresponding author
}

\begin{tabular}{|l|}
\hline Ke y w or d s \\
$\begin{array}{l}\text { Spinach, City } \\
\text { compost, Growth } \\
\text { and Yield }\end{array}$ \\
\hline Article Info \\
\hline Accepted: \\
22 July 2019 \\
Available Online: \\
10 August 2019 \\
\hline
\end{tabular}

A B S T R A C T

The present investigation was carried out at Dr. B.R. Ambedkar University of Social Sciences, Mhow, Madhya Pradesh to find out the effects of city compost on growth and yield of spinach during 2018-19. Spinach cv. All Green was used for the experiment with of different doses $(5,10,15$ and 20 t/ha) of city compost along with recommended dose of NPK fertilizers (100:60:60 kg NPK/ha). Maximum growth parameters (germination percentage, plant height, leaf length, leaf width and petiole length) were recorded with city compost @ $10 \mathrm{t} / \mathrm{ha}+50 \%$ of $\mathrm{RDF}\left(\mathrm{T}_{4}\right)$ followed by city compost @ $15 \mathrm{t} / \mathrm{ha}+25 \%$ of RDF $\left(\mathrm{T}_{5}\right)$. Whereas, the maximum average number of leave per plant and yield were recorded under city compost @ $10 \mathrm{t} / \mathrm{ha}+50 \%$ of RDF followed by city compost @ $15 \mathrm{t} / \mathrm{ha}+25 \%$ of RDF. This treatment has also registered the superior from economic point of view. Furthermore, the minimum values of growth and yield were recorded under control.

\section{Introduction}

Spinach (Spinacia oleracea L.) is an important leafy vegetable crop and gaining its popularity to all kinds of people due to its high carotene and vitamin $\mathrm{C}$ contents. Like other vegetable crops spinach also require fertilization for better yield and economics. Adequate fertilization, as a source of almost all the essential nutrients, is an important factor in crops growth (Ogunlela et al., 2005). The role of macronutrient particularly nitrogen $(\mathrm{N})$, phosphorus $(\mathrm{P})$ and potassium $(\mathrm{K})$ are very essential for proper growth; yield and quality produce throughout its life. Indiscriminate use of inorganic fertilizers affects the soil texture and structure, decreases the soil organic matter content and hinders the microbial activities in soil. Similarly increasing use of chemical fertilizers for growing vegetables such as spinach has caused numerous problems related to the environment and human health. On the other hand, organic agriculture is a production system that sustains the health of soils and 
ecosystems. Organic manures are source of macro and micronutrient in addition to plant growth molecules, which collectively lead to better crop yields (Masder et al., 2002). Moreover, manure enhances soil organic matter which consequently improves microbial activity, aeration, water holding capacity and finally, plant growth and yield (Mooleki et al., 2002 and Schoenau, 2006). Indore city compost is a organic manure being manufactured by Indore Municipal Corporation by door to door kitchen waste collection project under 'Swatcha Bharat Mission' programme. Keeping above in view an Iinvestigation on Effects of city compost on growth and yield of spinach (Spinacia oleracea L.) was formulated.

\section{Materials and Methods}

The present experiment was carried out at department of Horticulture, Dr. B.R. Ambedkar University of Social Sciences, Mhow, Madhya Pradesh during Rabi 2019 under protected condition. Six treatments including, $\mathrm{T}_{0}$ : Control (No fertilization), $\mathrm{T}_{1}$ : city compost @ 20 t/ha, $\mathrm{T}_{2}: 100 \%$ of RDF, $\mathrm{T}_{3}$ : city compost @ $5 \mathrm{t} / \mathrm{ha}+75 \%$ of RDF, $\mathrm{T}_{4}$ : city compost @ $10 \mathrm{t} / \mathrm{ha}+50 \%$ of RDF and $\mathrm{T}_{5}$ : city compost@15 t/ha + 25\% of RDF, were analyzed with spinach cultivar All Green. The experiments was formulated and replicated four times under randomized block design. Plant height, leaf length, leaf width and petiole length of plants were measured at 30, 45 and 60 days after sowing. Further, leaves were harvested from each plot and average number of leaves per plant and subsequently, yield in quintal per hectare was calculated. The total expenditure per hectare was worked out for all the treatments by adding all the costs (fertilizers and intercultural operations) for the purpose of experiment and values were expressed in rupees. The gross income was worked out after selling the harvested produce at prevailing market price (Rs. 20 per $\mathrm{kg}$ ), subsequently, the net income was calculated by subtracting the total expenditure from the gross return. Finally, the return per rupees invested i.e., benefit: cost ratio was calculated for all the treatments and compared with control. The statistical analysis was carried out for each observed character under the study using MS-Excel (2010), ICAR-Goa, Web Agri Stat Package (WASP 2.0) and OPSTAT software (Sheoran et al., 1998).

\section{Results and Discussion}

\section{Influence of city compost on growth parameters of spinach plant}

The data presented in Table 1. Clearly pointed out significant variation in growth parameters due to different treatments in spinach i.e. city compost and their combination with RDF. The maximum mean germination percentage $(86.76 \%)$ was recorded in city compost @ 10 $\mathrm{t} / \mathrm{ha}+50 \%$ of $\mathrm{RDF}\left(\mathrm{T}_{4}\right)$ and found significantly superior than rest of the treatments, followed by $82.25 \%$ in city compost @ 15 t/ha + 25\% of RDF $\left(\mathrm{T}_{5}\right)$ and $79.00 \%$ in city compost @ $5 \mathrm{t} / \mathrm{ha}+75 \%$ of RDF $\left(\mathrm{T}_{3}\right)$, whereas, minimum germination percentage $(56.83 \%)$ was recorded in control $\left(\mathrm{T}_{0}\right)$. The plant height $(22.03,30.72$ and 35.36 cms), leaf length (11.14, 13.40 and 15.58 $\mathrm{cms})$, leaf breath $(7.42,7.84$ and $10.23 \mathrm{cms})$ and petiole length $(11.34,13.90$ and 15.70 cms) were recorded in city compost @ 10 t/ha $+50 \%$ of $\mathrm{RDF}\left(\mathrm{T}_{4}\right)$, followed by in city compost @15 t/ha + 25\% of RDF $\left(\mathrm{T}_{5}\right)$ at 30, 45 and 60 DAS respectively and found statistically non-significant among each other. Whereas, the minimum values of plant height (19.47, 23.67 and $24.57 \mathrm{cms}$ ), leaf length (7.58, 8.88 and $11.68 \mathrm{cms})$, leaf breath $(6.17$, 7.26 and $8.41 \mathrm{~cm}$ ) and petiole length (8.91, 10.24 and $12.89 \mathrm{cms}$ ) were recorded in control $\left(\mathrm{T}_{0}\right)$. The observation made on leaf: petiole ratio revealed that there was non-significant effect on this parameter due to different 
treatments which might be attributed to slow release source of nutrients using organic source, this could have affected the growth of the plants during growth period of spinach, hence, the non-significant results obtained.

The results obtained can be justified from the fact that germination of seed is genetical behavior and it does not directly affects by addition of fertilizers or manures but the balanced application of organic and inorganic fertilizers results in higher germination. On the other hand, minimum germination of spinach seeds under control $\left(\mathrm{T}_{0}\right)$ plot might be due to direct effect of climate, soil moisture percentage and the characteristics of seed i.e., vitality and seed dormancy. Nitrogen, phosphorus and potassium are the primary plant nutrients affecting plant growth.

Soil amended of organic manure in combination with inorganic fertilizer could probably be attributed to NPK availability which promoted higher biomass during vegetative development and also helped to maintain functional leaf growth. As we know that organic matter of soil is important factor for receiving nutrients from soil to the plants, application of city compost in combination with recommended dose of fertilizer $\left(\mathrm{T}_{4}\right.$ and $\mathrm{T}_{5}$ ) have found to improve all the growth parameter studied, which might be attributed to fact that the available nutrients in soil as well as given nutrient in different treatments might have get accelerate due to improve soil physical condition using organic compost and resulted in improved growth of spinach plant. The above findings were found in conformity with results of Chat et al., (2005) and Roy et al., (2009) in spinach. Similarly, Akinbile et al., (2016), Sanni (2016) and Jakhro et al., (2017) noticed that application of organic manure in addition to chemical fertilizers increased growth of amaranthus and spinach plants. Further, Hossain and Ryu (2017) who found that application of organic fertilizer
(6.5, 13 and $26 \mathrm{t} / \mathrm{ha})$ and the recommended dose of chemical fertilizer significantly increased leaf length and breadth of lettuce.

Effects of city compost on yield and economic attributes in spinach

The data pertaining to yield attributing characters and economic observation of experiment are presented in Table 2. Which shows that there was significant difference due to different treatments in spinach during period of experiment. The maximum average number of leaves per plant at 30, 45 and 60 DAS $(12.35,16.88$ and 15.98) was recorded in city compost @ $10 \mathrm{t} / \mathrm{ha}+50 \%$ of RDF $\left(\mathrm{T}_{4}\right)$ and found significantly superior than rest of the treatments during period of experiment, followed by $10.85,14.50$ and 13.69 leaves at 30,45 and 60 DAS respectively in city compost @ 15 t/ha + 25\% of $\operatorname{RDF~}\left(\mathrm{T}_{5}\right)$. Subsequently, maximum yield at first, second and third cuttings (24.08, 35.83 and 32.32 $\mathrm{q} / \mathrm{ha}$ ) and total yield of $92.24 \mathrm{q} / \mathrm{ha}$ was recorded with city compost @ 10 t/ha + 50\% of RDF $\left(\mathrm{T}_{4}\right)$ and found significantly superior than rest of the treatments, followed by 18.91 , 29.40 and $27.37 \mathrm{q} / \mathrm{ha}$ at first, second and third cuttings, respectively as well as $75.67 \mathrm{q} / \mathrm{ha}$ as total yield with application of city compost @ $15 \mathrm{t} / \mathrm{ha}+25 \%$ of $\mathrm{RDF}\left(\mathrm{T}_{5}\right)$. Further, the statistically analysis of data revealed that the treatments $T_{2}, T_{3}$ and $T_{5}$ had no difference and hence, reported to be non-significant among each other's.

The maximum average number of leaves per plant in $\mathrm{T}_{4}$ followed by $\mathrm{T}_{5}$ might be attributed to precise application and distribution of city compost and inorganic fertilizers sources in soil, thereby, increasing the availability of nutrients which promoted protein synthesis and might have accelerated the mobility of photosynthates from source to the sink to induced higher vegetative growth in the form of leaves in spinach. 
Table.1 Effects of Selective combination of City compost and NPK Fertilization on growth of Spinach cv. All Green

\begin{tabular}{|c|c|c|c|c|c|c|c|c|c|c|c|c|c|c|c|c|}
\hline \multirow[t]{2}{*}{ Treatments } & \multirow[t]{2}{*}{$\begin{array}{c}\text { Germination } \\
\%\end{array}$} & \multicolumn{3}{|c|}{ Plant height (cm) } & \multicolumn{3}{|c|}{ Leaf length $(\mathrm{cm})$} & \multicolumn{3}{|c|}{ Leaf width $(\mathrm{cm})$} & \multicolumn{3}{|c|}{ Petiole length $(\mathrm{cm})$} & \multicolumn{3}{|c|}{$\begin{array}{c}\text { Leaf: petiole (Length } \\
\text { basis) }\end{array}$} \\
\hline & & $\begin{array}{c}\text { 30 } \\
\text { DAS }\end{array}$ & $\begin{array}{c}45 \\
\text { DAS }\end{array}$ & $\begin{array}{c}\text { 60 } \\
\text { DAS }\end{array}$ & $\begin{array}{c}\text { 30 } \\
\text { DAS }\end{array}$ & $\begin{array}{c}45 \\
\text { DAS }\end{array}$ & $\begin{array}{c}\text { 60 } \\
\text { DAS }\end{array}$ & $\begin{array}{c}30 \\
\text { DAS }\end{array}$ & $\begin{array}{c}45 \\
\text { DAS }\end{array}$ & $\begin{array}{c}60 \\
\text { DAS }\end{array}$ & $\begin{array}{c}\text { 30 } \\
\text { DAS }\end{array}$ & $\begin{array}{c}45 \\
\text { DAS }\end{array}$ & $\begin{array}{c}\text { 60 } \\
\text { DAS }\end{array}$ & $\begin{array}{c}\text { 30 } \\
\text { DAS }\end{array}$ & $\begin{array}{c}45 \\
\text { DAS }\end{array}$ & $\begin{array}{c}\text { 60 } \\
\text { DAS }\end{array}$ \\
\hline$T_{0}:$ Control & $56.83^{d}$ & $19.47^{\mathrm{c}}$ & $23.67^{d}$ & $24.57^{\mathrm{c}}$ & $7.58^{c}$ & $8.88^{d}$ & $11.68^{\mathrm{c}}$ & $6.17^{b}$ & 7.26 & $8.41^{d}$ & $8.91^{\mathrm{d}}$ & $10.24^{\mathrm{d}}$ & $12.89^{\mathrm{c}}$ & 0.85 & 0.87 & 0.91 \\
\hline $\begin{array}{l}T_{1}: \text { City compost @ } \\
20 \text { t/ha }\end{array}$ & $69.89^{c}$ & $20.02^{b c}$ & $25.02^{\mathrm{cd}}$ & $26.55^{b c}$ & $8.40^{\mathrm{bc}}$ & $10.47^{\mathrm{c}}$ & $12.70^{\mathrm{bc}}$ & $6.97^{b}$ & 7.72 & $9.09^{b c d}$ & $9.78^{\mathrm{cd}}$ & $11.61^{\mathrm{c}}$ & $13.50^{\mathrm{bc}}$ & 0.88 & 0.90 & 0.95 \\
\hline$T_{2}: 100 \%$ of $R D F$ & $72.23^{\mathrm{c}}$ & $20.52^{a b c}$ & $26.61^{b c}$ & $28.98^{b c}$ & $9.38^{b c}$ & $11.66^{b c}$ & $13.68^{\mathrm{ab}}$ & $6.18^{\mathrm{ab}}$ & 7.47 & $8.73^{\mathrm{cd}}$ & $9.79^{\mathrm{bc}}$ & $12.70^{\mathrm{bc}}$ & $14.38^{\mathrm{ab}}$ & 0.96 & 0.92 & 0.95 \\
\hline $\begin{array}{l}T_{3}: \text { City compost @ } \\
05 \text { t/ha }+75 \% \text { of } \\
R D F\end{array}$ & $79.00^{\mathrm{b}}$ & $20.83^{a b c}$ & $27.09^{b c}$ & $29.13^{b c}$ & $9.84^{\mathrm{ab}}$ & $12.61^{\mathrm{ab}}$ & $14.60^{\mathrm{a}}$ & $7.03^{\mathrm{a}}$ & 7.75 & $9.23^{\mathrm{bc}}$ & $10.21^{\mathrm{b}}$ & $13.40^{\mathrm{ab}}$ & $15.23^{\mathrm{a}}$ & 0.96 & 0.94 & 0.96 \\
\hline $\begin{array}{l}T_{4}: \text { City compost @ } \\
10 \mathrm{t} / \mathrm{ha}+50 \% \text { of } \\
R D F\end{array}$ & $86.76^{\mathrm{a}}$ & $22.03^{\mathrm{a}}$ & $30.72^{\mathrm{a}}$ & $35.36^{\mathrm{a}}$ & $11.14^{\mathrm{a}}$ & $13.40^{\mathrm{a}}$ & $15.58^{\mathrm{a}}$ & $7.42^{\mathrm{a}}$ & 7.84 & $10.23^{\mathrm{a}}$ & $11.34^{\mathrm{a}}$ & $13.90^{\mathrm{a}}$ & $15.70^{\mathrm{a}}$ & 0.98 & 0.96 & 0.99 \\
\hline $\begin{array}{l}T_{5}: \text { City compost @ } \\
15 \text { t/ha }+25 \% \text { of } \\
R D F\end{array}$ & $82.25^{\mathrm{b}}$ & $21.37^{\mathrm{ab}}$ & $29.06^{\mathrm{ab}}$ & $30.14^{\mathrm{b}}$ & $10.24^{\mathrm{ab}}$ & $12.80^{\mathrm{ab}}$ & $14.75^{\mathrm{a}}$ & $7.33^{\mathrm{a}}$ & 7.76 & $9.50^{\mathrm{ab}}$ & $10.63^{\mathrm{ab}}$ & $13.52^{\mathrm{ab}}$ & $15.27^{\mathrm{a}}$ & 0.97 & 0.95 & 0.97 \\
\hline S.Em. \pm & 1.21 & 0.53 & 0.89 & 1.64 & 0.37 & 0.42 & 0.82 & 0.27 & 0.52 & 0.25 & 0.42 & 0.39 & 0.46 & 0.06 & 0.03 & 0.10 \\
\hline C.D. at $5 \%$ & 3.66 & 1.60 & 2.68 & 4.94 & 1.11 & 1.27 & 2.47 & 0.83 & N.S. & 0.74 & 1.26 & 1.17 & 1.37 & N.S. & N.S. & N.S. \\
\hline C.V. & 3.26 & 5.14 & 6.58 & 11.26 & 7.84 & 7.22 & 11.83 & 8.00 & 13.51 & 5.35 & 8.30 & 6.16 & 6.28 & 12.17 & 5.92 & 13.44 \\
\hline
\end{tabular}


Table.2 Effects of Selective combination of City compost and NPK Fertilization on yield attributes and economics of spinach cv. All Green

\begin{tabular}{|c|c|c|c|c|c|c|c|c|c|c|c|}
\hline \multirow[t]{2}{*}{ Treatments } & \multicolumn{3}{|c|}{$\begin{array}{l}\text { Average no. of leaves/ } \\
\text { plant }\end{array}$} & \multicolumn{4}{|c|}{ Yield (q/ha) } & \multirow{2}{*}{$\begin{array}{c}\text { Total } \\
\text { expenditu } \\
\text { re (Rs.) }\end{array}$} & \multirow{2}{*}{$\begin{array}{c}\text { Gross } \\
\text { income } \\
\text { (Rs.) }\end{array}$} & \multirow{2}{*}{$\begin{array}{c}\text { Net } \\
\text { income } \\
\text { (Rs.) }\end{array}$} & \multirow[t]{2}{*}{$\begin{array}{l}\text { B: } \mathrm{C} \\
\text { ratio }\end{array}$} \\
\hline & $\begin{array}{l}\text { 30 } \\
\text { DAS }\end{array}$ & $\begin{array}{l}45 \\
\text { DAS }\end{array}$ & $\begin{array}{l}\text { 60 } \\
\text { DAS }\end{array}$ & $\begin{array}{l}\text { 30 } \\
\text { DAS }\end{array}$ & $\begin{array}{l}45 \\
\text { DAS }\end{array}$ & 60 DAS & Total & & & & \\
\hline$T_{0}:$ Control & $7.35^{\mathrm{d}}$ & $7.93^{\mathrm{e}}$ & $8.45^{\mathrm{d}}$ & $8.15^{\mathrm{d}}$ & $10.35^{\mathrm{e}}$ & $11.75^{d}$ & $30.25^{\mathrm{e}}$ & 19450.00 & $\begin{array}{c}60502.1 \\
8\end{array}$ & 41052.18 & $1: 2.11$ \\
\hline $\begin{array}{l}T_{1}: \text { City compost @20 } \\
\text { t/ha }\end{array}$ & $8.85^{c}$ & $10.54^{d}$ & $11.00^{\mathrm{c}}$ & $12.56^{\mathrm{c}}$ & $18.82^{d}$ & $20.40^{\mathrm{c}}$ & $51.77^{d}$ & 80950.00 & $\begin{array}{c}103537 . \\
95\end{array}$ & 22587.95 & 1: 0.28 \\
\hline$T_{2}: 100 \%$ of $R D F$ & $8.90^{c}$ & $\underset{\mathrm{d}}{11.20^{\mathrm{c}}}$ & $11.05^{\mathrm{c}}$ & $13.51^{\mathrm{c}}$ & $20.04^{d}$ & $20.88^{\mathrm{c}}$ & $\underset{\mathrm{d}}{54.41^{\mathrm{c}}}$ & 25877.47 & $\begin{array}{c}108822 \\
89\end{array}$ & 82945.42 & $1: 3.21$ \\
\hline $\begin{array}{l}T_{3}: \text { City compost @05 } \\
\text { t/ha }+75 \% \text { of } R D F\end{array}$ & $9.13^{c}$ & $12.25^{\mathrm{c}}$ & $\underset{c}{11.85^{b}}$ & $14.32^{c}$ & $24.58^{c}$ & $23.68^{b c}$ & $62.57^{\mathrm{c}}$ & 39647.08 & $\begin{array}{c}125145 . \\
87\end{array}$ & 85498.79 & $1: 2.16$ \\
\hline $\begin{array}{l}T_{4}: \text { City compost @ } 10 \\
\text { t/ha }+50 \% \text { of } R D F\end{array}$ & $12.35^{\mathrm{a}}$ & $16.88^{\mathrm{a}}$ & $15.98^{\mathrm{a}}$ & $24.09^{\mathrm{a}}$ & $35.83^{\mathrm{a}}$ & $32.32^{\mathrm{a}}$ & $92.24^{\mathrm{a}}$ & 53413.74 & $\begin{array}{c}184477 . \\
62\end{array}$ & $\begin{array}{c}131063.8 \\
8\end{array}$ & $1: 2.45$ \\
\hline $\begin{array}{l}T_{5}: \text { City compost @ } 15 \\
\text { t/ha }+25 \% \text { of } R D F\end{array}$ & $10.85^{b}$ & $14.50^{\mathrm{b}}$ & $13.69^{b}$ & $18.91^{b}$ & $29.40^{\mathrm{b}}$ & $27.37^{\mathrm{ab}}$ & $75.68^{b}$ & 67181.87 & $\begin{array}{c}151345 . \\
47\end{array}$ & 84163.61 & $1: 1.25$ \\
\hline S.Em. \pm & 0.40 & 0.50 & 0.88 & 1.44 & 1.47 & 1.93 & 2.93 & - & - & - & - \\
\hline C.D. at $5 \%$ & 1.19 & 1.51 & 1.88 & 4.33 & 4.42 & 5.81 & 8.81 & - & - & - & - \\
\hline C.V. & 8.26 & 8.19 & 10.38 & 18.84 & 12.66 & 16.95 & 9.57 & - & - & - & - \\
\hline
\end{tabular}

*Within a column, means followed by the same letter are not significantly different at $\mathrm{P} \leq 0.05$ using Duncan's multiple range test 
Further, it is narrated by (Saeed et al., 2001) that the optimum plant height is claimed to be positively correlated with productivity of plants. The findings of present investigation showed that treatment $T_{4}$ followed by $T_{5}$ recorded higher yield which might be due to efficient utilization of NPK fertilizers in combination with city compost which could have improved $\mathrm{C}$ : $\mathrm{N}$ ratio, more organic matter build up, enhanced microbial activity, better root proliferation and accelerated transport of plant nutrients in higher concentration. The above findings are in conformity with Kansal et al., (1981), Ansari (2008), Canali et al., (2008) and Patel et al., (2008) who observed that application of organic manure in combination with inorganic fertilizer produced higher yield in spinach plants. Lim and Vimala (2012)

The data pertaining to economic of the experiment viz., total expenditure, gross income, net income and benefit: cost ratio under different treatments has been presented in Table 2. The scrutiny of data revealed that total expenditure was Rs. 80950.00/ha with city compost @ $20 \mathrm{t} / \mathrm{ha}\left(\mathrm{T}_{1}\right)$ followed by Rs. 67181.87 with city compost @ 15 t/ha +25\% of RDF $\left(\mathrm{T}_{5}\right)$, whereas, lowest expenditure (Rs. 19450.00/ha) was in control $\left(\mathrm{T}_{0}\right)$. The maximum yield was recorded in $\mathrm{T}_{4}$ followed by $\mathrm{T}_{5}$, therefore, based on yield obtained in individual treatments, the highest gross income (Rs. 184477.62/ha) was recorded in $\mathrm{T}_{4}$, followed by Rs. $151345.47 / \mathrm{ha}$ in $\mathrm{T}_{5}$, whereas, lowest gross income (Rs. 60502.18/ha) was calculated in $\mathrm{T}_{0}$. Hence, after deducting the total expenditure from the gross income of corresponding treatments, the highest net income (Rs. 131063.88/ha) was calculated in $\mathrm{T}_{4}$, whereas it was found lowest (Rs. 41052.18/ha) under $\mathrm{T}_{0}$. Finally, after considering the all inputs, the benefit: cost ratio was calculated maximum (3.21) under $\mathrm{T}_{2}$ followed by 2.45 under $\mathrm{T}_{4}$, probably due to addition of low inputs under $\mathrm{T}_{2}$, however, treatment $\mathrm{T}_{4}$ reported to appear superior in all parameters studied and hence, $\mathrm{T}_{4}$ could be considered as best treatment for spinach cultivation. On the other hand, lowest B: C ratio obtained under $T_{1}(0.28)$ and $T_{0}(2.11)$ treatments might be attributable to least performance of plant under study because of incomplete and no fertilization respectively.

It can be concluded that spinach cv. All Green is highly responsive to combined application of city compost and inorganic source of nutrition. Application of city compost @ 10 $\mathrm{t} / \mathrm{ha}+50 \%$ of $\mathrm{RDF}\left(\mathrm{T}_{4}\right)$ followed by city compost@15 t/ha $+25 \%$ of RDF $\left(\mathrm{T}_{5}\right.$, were found superior for improving growth and yield of spinach. Thus, based on overall performance, it can be concluded that fertilization with city compost @ $10 \mathrm{t} / \mathrm{ha}+50$ $\%$ of RDF $\left(\mathrm{T}_{4}\right)$ found best in spinach cv. All Green under protected condition.

\section{Acknowledgement}

Authors are very thankful to the administrative and academic member of Dr. B.R. Ambedkar University of Social Sciences, Ambadker Nagar (Mhow) for providing support for conducting research trial.

\section{References}

Akinbile, C.O., Adefolaju, S. and Ajibade, F.O. 2016. Effect of organic and inorganic fertilizer on the growth and yield of Amaranthus curentus in akure, ondo state, Nigeria. $37^{\text {th }}$ Annual Conference and Annual General Meeting, Minna, Pp. 337-343.

Ansari, A.A. 2008. Effect of Vermicompost and vermiwash on the productivity of spinach (Spinacia oleracea), onion (Allium cepa) and potato (Solanum tuberosum). World Journal of Agricultural Sciences, 4(5): 554-557. 
Canali, S., Montemurro, F., Tittarelli, F. and Masetti, O. 2008. Effect of nitrogen fertilisation reduction on yield, quality and $\mathrm{N}$ utilisation of processing spinach. Journal of Food, Agriculture \& Environment, 6(3\&4): 242-247.

Chat, T.H., Dung, N.T., Binh, D.V. and Preston, T.R. 2005. Effect on yield and composition of water spinach (Ipomoea aquatica), and on soil fertility, of fertilization with worm compost or urea. Livestock Research for Rural Development, 17(10): 20-25.

Cho, M.J., Howard, L.R., Prior, R.L., Morelock, T. 2008. Flavonoid content and antioxidant capacity of spinach genotypes determined by highperformance chromatography/mass spectrometry. Journal of Science and Food Agriculture, 88(6): 1099-1106.

Hossain, M.B. and Ryu, K.S. 2017. Effects of organic and inorganic fertilizers on lettuce (Lactuca sativa L.) and soil properties. SAARC Journal of Agriculture, 15(2): 93-102.

Jakhro, M.I., Shah, S.I., Amanullah, Zehri, M.Y., Rahujo, Z.A., Ahmed, S., Ahmed, S. and Jakhro, M.A. 2017. Growth and yield of spinach (Spinacia oleracea L.) under fluctuating levels of organic and inorganic fertilizers. International Journal of Development Research, 7(2): 11454-11460.

Kansal, B.D., Singh, B., Bajaj, K.L. and Kaur, G. 1981. Effect of different levels of nitrogen and farmyard manure on yield and quality of spinach (Spinacea oleracea L.). Plant Foods for Human Nutrition, 31:163-170.

Lim, A.H. and Vimala, P. 2012. Growth and yield responses of four leafy vegetables to organic fertilizer. Journal of Tropical Agriculture and Food Science, 40(1): 111.

Masder, P., Filebach, A., Dubois, D., Gunst,
L., Fried, P. and Niggli, U. 2002. Soil fertility and biodiversity in organic farming science, 296: 1694-1697.

Mooleki, S.P., Schoenau, J.J., Hultgreen, G., Wen, G. and Charles, JL. 2002. Effect of rate, frequency and method of liquid swine manure application on soil nitrogen availability, crop performance and $\mathrm{N}$ use efficiency in east-central Saskatchewan. Canadian Journal of Soil Science, 82: 457-467.

Ogunlela, V.B., Masarirambi, M.T., Makuza, S.M. 2005. Effect of cattle manure application on pod yield and yield indices of okra (Abelmoschus esculentus L. Moench) in semi-arid and subtropical environment. Journal of Food and Agriculture Environment, 3: 5-15.

Patel, K.C., Patel, K.P., Ramani, V.P. and Patel, J.C. 2008. Effect of Pb and FYM application on spinach yield, $\mathrm{Pb}$ uptake and different fractions of $\mathrm{Pb}$ in sewage irrigated Fluventic ustochrepts soils of peri urban area of Vadodara. An Asian Journal of Soil Science, 3(2): 230-235.

Roy, O.P., Saha, B.K. and Chowdhury, M.A.H. 2009. Integrated nutrient management of Spinach. Journal of Agrofoestry and Environment, 3(1): 5760.

Saeed, I.N., Abbasi, K. and Kazim, M. 2001. Response of maize (Zea mays) to nitrogen and phosphorus fertilization under agro-climatic condition of Rawalokot Azad Jammu and Kashmir. Pakistan Journal of Biological Science, 4: 53-55.

Sanni, K.O. 2016. Effect of compost, cow dung and NPK 15-15-15 fertilizer on growth and yield performance of Amaranth (Amaranthus hybridus). International Journal of Advances in Scientific Research, 2(3): 076-082.

Schoenau, J.J. 2006. Benefits of long-term application of manure. Advance in Pork Production, 17: 153-158. 
Sheoran, O.P., Tonk, D.S., Kaushik, L.S., Hasija, R.C. and Pannu, R.S. 1998. Statistical software package for agricultural research workers. Recent Advances in information theory,
Statistics and computer applications by D.S. Hooda and R.C. Hasija, department of mathematics statistics, CCS HAU, Hisar, Haryana, 139-143.

\section{How to cite this article:}

Nilesh Nirgude, D. K. Mishra, Raj Kumar Dhakad and Deepak Singune. 2019. Influence of Selective Combination of City Compost and NPK Fertilization on Growth and Yield of Spinach (Spinacia oleracea L.). Int.J.Curr.Microbiol.App.Sci. 8(08): 2725-2732.

doi: https://doi.org/10.20546/ijcmas.2019.808.314 